$\star$ Polityki Europejskie,

* Finanse i Marketing

$\star \star \star 20$ (69) 2018

DOI 10.22630/PEFIM.2018.20.69.38

Malgorzata Raczkowska

Szkoła Gtówna Gospodarstwa Wiejskiego

Kinga Gruziel

Szkoła Główna Gospodarstwa Wiejskiego

\title{
Ubóstwo i wykluczenie społeczne w Unii Europejskiej w relacji miasto-wieś
}

\section{POVERTY AND SOCIAL EXCLUSION IN THE EUROPEAN UNION IN URBAN-RURAL RELATIONS}

Artykut podejmuje zagadnienia odnoszqce się do istoty i pomiaru ubóstwa oraz wykluczenia społecznego $w$ dużych miastach oraz na obszarach wiejskich $w$ Unii Europejskiej. Praca została napisana na podstawie przegladu literatury przedmiotu oraz danych statystycznych Eurostat-u. $W$ części teoretycznej przedstawiono definicje oraz mierniki stużqce do oceny analizowanych zjawisk społecznych. Uzyskane wyniki potwierdzity wyższy poziom zagrożenia ubóstwem $i$ wykluczeniem społecznym na obszarach wiejskich Wspólnoty. Ponadto w większośsi krajów unijnych ubóstwo relatywne na wyższym poziomie zaobserwowano na wsi, a głębokq deprywacje materialnq oraz niskq intensywność pracy $w$ dużych aglomeracjach miejskich.

Słowa kluczowe: ubóstwo, granice ubóstwa, wykluczenie społeczne, deprywacja materialna, niska intensywność pracy

\section{Wstęp}

Ubóstwo, wykluczenie społeczne z jednej strony mają charakter indywidualny, są synonimem określonych warunków życia jednostki - osoby, rodziny, gospodarstwa domowego - jej warunków materialnych oraz kondycji psychospołecznej. Z drugiej strony są ważnymi problemami społecznymi wówczas, gdy charakteryzujące ich sytuacje przybierają taką skalę i nasilenie, że stają się istotnym składnikiem warunków życia całych grup społecznych.

W systemach państw opiekuńczych brak jest dyskusji nad problemem czy redukować ubóstwo i wykluczenie społeczne. Przedmiot badań obejmuje przede wszystkim trafną identyfikację owych zjawisk i opracowanie skutecznych metod ich zmniejszania przez systemy społeczne.

W oparciu o dane empiryczne i kwerendę literatury celem głównym pracy była identyfikacja, porównanie oraz ocena rozmiarów ubóstwa i wykluczenia społecznego w krajach Unii Europejskiej w perspektywie terytorialnej. W związku z powyższym celem sprecyzowano ogólną hipotezę badawczą: ubóstwo i wykluczenie społeczne na 


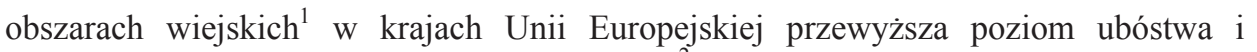
wykluczenia występującego w dużych miastach. ${ }^{2}$

\section{Dane i metody}

Do pomiaru wykluczenia społecznego wykorzystywane są różne wskaźniki opisujące poszczególne wymiary ekskluzji. ${ }^{3}$ Są one podstawą badań nad ubóstwem, gdyż identyfikują skalę, obszary i przyczyny wykluczenia społecznego oraz związanego z nim ryzyka.

Przyjmując uproszczone założenia dla potrzeb tego artykułu oraz uzależniając ubóstwo i wykluczenie społeczne jedynie od ekonomicznych aspektów do analizy wykorzystano sumaryczny wskaźnik „Ludność zagrożona ryzykiem ubóstwa i wykluczeniem społecznym", obejmujący: ${ }^{4}$

1. wskaźnik zagrożenia ubóstwem po transferach socjalnych,

2. wskaźnik poważnej deprywacji materialnej,

3. wskaźnik niskiego wykorzystania zasobów pracy.

Wskaźnik zagrożenia ubóstwem lub wykluczeniem społecznym uwzględnia osoby, które zostały ujęte przynajmniej w jednym z trzech ww. wskaźników.

Pierwszy z mierników - wskaźnik zagrożenia ubóstwem - zaliczany jest do grupy wskaźników o charakterze relatywnym. Według metodologii Eurostatu za zagrożone ubóstwem uważa się „osoby żyjące w gospodarstwach domowych, których dyspozycyjny dochód ekwiwalentny jest niższy od granicy zagrożenia ubóstwem ustalonej na poziomie $60 \%$ mediany dyspozycyjnego ekwiwalentnego dochodu w danym kraju".

Deprywacja materialna rozumiana jest jako „wymuszony względami ekonomicznymi brak kombinacji pozycji z listy dóbr obrazujących materialne warunki życia, takie jak posiadanie konkretnych dóbr trwałego użytku oraz możliwości pozwolenia sobie na zaspokojenie określonych podstawowych potrzeb". ${ }^{6} \mathrm{~W}$ takim ujęciu jest to wskaźnik ubóstwa bezwzględnego (absolutnego). W Strategii Europa 2020 za „dotknięte poważną deprywacją materialną” przyjęto osoby, które nie mogą pozwolić sobie na zaspokojenie co najmniej 4 z 9 następujących potrzeb/dóbr/urządzeń uznanych we współczesnych warunkach europejskich za podstawowe: opłacenia tygodniowego wyjazdu wszystkich członków gospodarstwa domowego na wypoczynek raz w roku; spożywania mięsa, ryb (lub wegetariańskiego odpowiednika) co drugi dzień; ogrzewania mieszkania odpowiednio do potrzeb; pokrycia niespodziewanego wydatku (w wysokości odpowiadającej miesięcznej wartości granicy ubóstwa relatywnego, przyjętej w danym kraju, w roku poprzedzającym badanie); terminowego regulowania opłat związanych z mieszkaniem, spłatą rat i kredytów; posiadania telewizora kolorowego; posiadania samochodu; posiadania pralki; posiadania telefonu (stacjonarnego lub komórkowego). ${ }^{7}$

\footnotetext{
${ }^{1} \mathrm{~W}$ pracy terminy: obszary wiejskie, tereny wiejskie, wieś stosowane są zamiennie.

${ }^{2}$ Za metodologią Eurostatu przyjęto: duże miasta o liczbie ludność $>50000$, obszary wiejskie o ludności $<5000$.

${ }^{3}$ Terminy wykluczenie społeczne i ekskluzja w pracy stosowane są zamiennie.

${ }^{4}$ Wskaźnik ten został opracowany przez Komisję Europejską w ramach Strategii Europa 2020.

${ }^{5}$ Polska w Unii Europejskiej w 2004-2014, GUS, Warszawa 2014, s.80.

${ }^{6}$ Combating poverty and social exclusion: A statistical portrait of the European Union 2010, Eurostat, http://2010againstpoverty.europa.euhttp://2010againstpoverty.europa.eu [odczyt:12.05.2018].

${ }^{7}$ Polska w Unii Europejskiej w 2014-2014, GUS, Warszawa 2014, s.80.
} 
Jedną z najczęściej wymienianych przyczyn ubóstwa jest brak pracy, dlatego trzeci wskaźnik dotyczy „osób żyjących w gospodarstwach domowych o bardzo małej intensywności pracy". Intensywność pracy mierzona jest jako "stosunek liczby miesięcy jaką wszyscy będący w wieku zdolności do pracy pracowali w danym roku do łącznej liczby miesięcy, w ciagu których mogliby pracować". ${ }^{8}$ Wskaźnik ten obejmuje osoby w wieku 0-59 lat żyjące w gospodarstwach domowych o bardzo niskiej intensywności wykorzystania pracy, tj. gdzie w minionym roku dorośli pracowali w wymiarze mniejszym niż $20 \%$ ich całkowitego potencjału pracy.

W analizie wykorzystano dane z lat 2013-2016. Zestawienie tych okresów pozwoliło na ocenę stopnia oraz dynamiki zmian badanych zjawisk. Metodyka zastosowana $\mathrm{w}$ artykule to analiza literatury przedmiotu oraz danych statystycznych Eurostatu.

\section{Ubóstwo i wykluczenie społeczne - przegląd pojęć}

Podstawowym elementem mającym istotne znaczenie dla pomiaru danej kategorii jest jej zdefiniowanie. Brak bowiem precyzyjnej i ogólnie akceptowanej definicji powoduje występowanie licznych rozbieżności zarówno w ocenach zasięgu, jak i w koncepcjach jego zwalczania. W literaturze przedmiotu prezentowane są różne sposoby pojmowania zarówno ubóstwa, jak i wykluczenia społecznego.

Problem ubóstwa istnieje od zawsze. Na przestrzeni wieków ulegał on różnym przeobrażeniom - zmianie podlegało zarówno rozumienie, definiowanie, mierzenie, jak i sposób traktowania go przez społeczeństwo. ${ }^{9}$ Pierwotnie ubóstwo było określane jako „brak możliwości zaspokojenia podstawowych potrzeb człowieka” i taka definicja została wprowadzona na początku XX wieku przez angielskiego socjologa Seebohma Rowntree. ${ }^{10} \mathrm{~W} 1901$ roku opracował on kategorię minimum środków żywnościowych koniecznych do biologicznej i psychicznej egzystencji, odnoszącej się następnie do nierówności w rozkładzie własności środków produkcji i dystrybucji dóbr. Brytyjskiego badacza można określić mianem głównego autora podejścia do ubóstwa jako kategorii absolutnej, gdzie jednostki (osoby czy gospodarstwa domowe) są określane jako ubogie, kiedy ich potrzeby nie są zaspokojone w sposób wystarczający, przy czym poziom zaspokojenia tych potrzeb nie jest odnoszony do poziomu zaspokojenia potrzeb innych członków społeczeństwa. ${ }^{11}$

Zgodnie z nurtem badawczym Rowntree ubóstwo definiowali Paul Samuelson i William Nordhaus. Według nich ubóstwo ma przede wszystkim wymiar materialny i odnosi się do „dochodu niewystarczającego do opłacenia podstawowych zasobów żywności, odzieży, dachu nad głową i innych artykułów pierwszej potrzeby" ${ }^{12}$ Inna z definicji ubóstwa wskazuje podobnie określając ubóstwo ,jako stan oznaczający brak wystarczających zasobów do dyspozycji czyli taki stan braku wystarczających

\footnotetext{
${ }^{8}$ Ibidem.

9 Kumor I., Ubóstwo ujęcie teoretyczne, Edukacja Humanistyczna nr 1 (24), Towarzystwo Wiedzy Powszechnej, Szczecin 2011, s.101.

10 Błaszczak-Przybycińska I., Metody pomiaru granic ubóstwa, Wiadomości Statystyczne nr 11, Zakład Wydawnictw Statystycznych, Warszawa 1990, s.10.

11 Rusnak Z., Pomiar ubóstwa i wykluczenia społecznego - problemy metodologiczne, Zeszyty Naukowe Wyższej Szkoły Bankowej we Wrocławiu Nr 20/2011, Wrocław 2011, s.338.

${ }^{12}$ Samuelson P., Nordhaus W., Ekonomia, Rebis, Poznań 2014, str.333.
} 
dochodów, który mógłby zapewnić minimalny standard życia". ${ }^{13}$ Inaczej można powiedzieć, że ubóstwo jest sytuacja, która charakteryzuje się różnego rodzaju brakami, które uniemożliwiają danej jednostce zaspokojenie podstawowych potrzeb. ${ }^{14}$

Badaczami skłaniającymi się do postrzegania ubóstwa nie tylko $\mathrm{w}$ aspekcie niewystarczających dochodów byli między innymi Amartya Sen oraz Peter Townsend. Sen $\mathrm{w}$ definiowaniu ubóstwa, podobnie jak w podejściu do nierówności, najbardziej zwracał uwagę na psychologiczno-socjologiczne cechy ludzi. W jego opinii ubóstwo to „nie tylko niewystarczające dochody, ale także bariery w dostępie do realizacji potrzeb życiowych zgodnie z poziomem własnego rozwoju i aspiracji”. ${ }^{15} \mathrm{Z}$ kolei Townsend $\mathrm{w}$ swoich badaniach odnosił się średniego społecznego standardu życia. Podkreślał zatem, że ubóstwo ma charakter relatywny, a nie absolutny. Według niego „ubóstwo stanowi bowiem brak wystarczających zasobów potrzebnych, by zaspokoić społecznie uznane potrzeby i uczestniczyć w życiu ogółu społeczeństwa". ${ }^{16}$ Podobnie do koncepcji Townsenda stwierdza Kazimierz Frieske, według niego ,ubóstwo to wcale nie tylko brak pieniędzy, to raczej takie szczególne okoliczności, które nie pozwalają ludziom nimi dotkniętymi na uczestnictwo w życiu zbiorowym $\mathrm{i}$ - zwłaszcza - w istotny sposób pomniejszają ich możliwości uczestnictwa w podstawowych instytucjach społecznych, od rodziny poczynając, na wymiarze sprawiedliwości kończąc. Mówiąc inaczej, ubóstwo to niezrealizowane warunki społecznej partycypacji". ${ }^{17}$

Poprzez nawiązanie do wymiaru partycypacji społecznej, badania nad ubóstwem w sposób bezpośredni przełożyły się na politykę i działania w zakresie walki z ubóstwem i wykluczeniem społecznym. Bowiem ubóstwo to nie tylko kwestia przetrwania, ale zdolności do uczestnictwa w zwykłych aktywnościach, które składają się na normalne życie społeczności. Jeżeli zasoby (nie tylko dochody, ale też usługi społeczne i inne) są za małe by uczestniczyć $w$ takich aktywnościach, to mamy do czynienia z ubóstwem, które często staje się zasadniczą przyczyną wykluczenia społecznego.

Często podkreśla się, że wykluczenie społeczne ma cechy ubóstwa i najczęściej jest jego bezpośrednim efektem. Stanisława Golinowska zwraca uwagę na fakt, że gdy rozszerza się kategorię ubóstwa, nie ograniczając jej wyłącznie do zasobów finansowych, lecz uwzględniając inne sfery życia (np. mieszkanie, edukację, zdrowie), wówczas pojęcie to przybliża się do pojęcia wykluczenia społecznego, jako że ubóstwo bardzo często współwystępuje z wykluczeniem społecznym lub oba zjawiska na siebie zachodza. ${ }^{18}$

Idea wykluczenia społecznego pojawiła się na początku lat 70 . XX wieku we Francji, w reakcji na nieszczelności francuskiego systemu zabezpieczenia

\footnotetext{
${ }^{13}$ Szopa B., Wokół zagadnień ubóstwa i bogactwa, Uniwersytet Ekonomiczny w Krakowie, Kraków 2012, s.81.

${ }^{14}$ Dyczewski L., Kościół katolicki wobec ubóstwa i ludzi ubogich, [w:] Polska bieda II, red. S. Golinowska, IPiSS, Warszawa 1997, s.370-371.

${ }^{15}$ Sen A., Nierówności. Dalsze rozważania, Społeczny Instytut Wydawniczy Znak, Kraków 2000, s.98.

${ }^{16}$ Chmielewski P., Znaczenie definicji biedy w wyznaczaniu granicy ubóstwa, Finanse i Prawo Finansowe, Journal of Finance and Financial Law, Łódź 2016, s.42.

${ }^{17}$ Frieske K., Bieda - miary i interpretacje [w:] S. Golinowska (red.), Polska bieda. Kryteria. Ocena. Przeciwdziałanie, IPISS, Warszawa 1997, s.236.

${ }^{18}$ Golinowska S., Wykluczenie społeczne, [w:] S. Golinowska, Z. Morecka, M. Styrc, E. Cukrowska, J.

Cukrowski (red.), Od ubóstwa do wykluczenia społecznego, IPiSS, Warszawa 2008, s.116-117.
} 
społecznego. ${ }^{19}$ Po raz pierwszy użył tego terminu w 1974 r. francuski minister Dobrobytu Społecznego R. Lenoir w książce Les Excluse z w odniesieniu do osób żyjących na marginesie życia społecznego. ${ }^{20}$

Koncepcja wykluczenia społecznego w literaturze przedmiotu jest z reguły utożsamiana z nierównościami społecznymi, dyskryminacją i powstaniem w strukturze społecznej grupy osób zaliczanych do kategorii underclass. ${ }^{21}$ Ze względu na wielowymiarowy charakter wykluczenia społecznego trudno jest stworzyć jego jedną, syntetyczną definicję. Dlatego dla porządku należy mówić o grupach definicyjnych, a nie o pojedynczych ujęciach zjawiska. Można wskazać na trzy najczęściej cytowane grupy.

Pierwsza z nich obejmuje definicje, gdzie wykluczenie społeczne odnoszone jest do kategorii ubóstwa relatywnego. W tym obszarze mieszczą się definicje Moisio czy Estivilia. Według definicji Pasi Moisio „być społecznie wykluczonym oznacza, że jednostka, rodzina albo nawet cała grupa są wyłączone ze sposobu życia, zasobów oraz warunków życia, jakie przeciętne występują w danej społeczności"22. Natomiast według Jordiego Estivilla ,wykluczenie społeczne może być pojmowane jako stan stopniowego wypadania z centralnych obszarów ekonomii, polityki i społeczeństwa, wynikający z procesów zachodzących na tych obszarach i połączony ze stopniową izolacją osób, grup, społeczności i terytoriów oraz lokowaniem ich na pozycjach niższości/gorszych w odniesieniu do centrów rozwoju/możliwości, zasobów i dominujących wartości". 23

Druga grupa to definicje, które określają ekskluzję jako proces. Charles Gore, Jose Figueiredo jednoznacznie definiują wykluczenie społeczne jako „dynamiczny i wielowymiarowy proces pełnego odcięcia lub częściowego ograniczania dostępu do różnych społecznych, gospodarczych, kulturowych i politycznych systemów, które pomagają jednostce w integracji ze społeczeństwem". ${ }^{24}$ Natomiast zgodnie z koncepcją Anthony Giddensa wykluczenie społeczne to ,proces i efekt różnego rodzaju upośledzeń społecznych, wskutek których jednostka lub grupa nie może w pełni uczestniczyć w życiu gospodarczym, społecznym, ekonomicznym i politycznym społeczeństwa, do którego należy". ${ }^{25}$ Upośledzenia te trwają na tyle długo, że jednostka zostaje wykluczona z życia społecznego.

\footnotetext{
${ }^{19}$ Becker-Pestka D., Kubiński G., Łojko M., Różne obszary wykluczenia społecznego w Polsce - wybrane zagadnienia, Exante, Wrocław 2017, s.7.

${ }^{20}$ Grewiński M., Polityka przeciwdziałania wykluczeniu społecznemu w Polsce i UE [w:] M. Sabal (red.), Potencjał tkwi w relacjach. Działania Regionalnego Ośrodka Polityki Społecznej w Krakowie na rzecz poprawy relacji międzyludzkich, Regionalny Ośrodek Polityki Społecznej, Kraków 2014, s.14.

${ }^{21}$ Nowak A. Pojęcie, istota, przyczyny, mechanizmy marginalizacji i wykluczenia społecznego http://bazhum.muzhp.pl/media//files/Chowanna/Chowanna-r2012-t1/Chowanna-r2012-t1-s17-32/Chowannar2012-t1-s17-32.pdf, [odczyt:5.06.2018].

${ }^{22}$ Moisio P., The Nature of Social Exclusion - Spiral of Precariousness or Statistical Category?, [w:] Social Exclusion in European Welfare States, ed. by R.J.A. Muffels, P. Tsakloglou, D.G. Mayes, Edward Elgar Publishing, Cheltenham UK/Northampton USA 2002, s.12.

${ }^{23}$ Estivill J., Concepts and Strategies for Combating Social Exclusion. An overview, International Labour Office, Genewa 2003, s.19.

${ }^{24}$ Gore C., Figueiredo J.B., Wykluczenie społeczne i polityka przeciwdziałania ubóstwu, Problemy Polityki Społecznej nr 5, IPISS, Warszawa 2003, s.18.

${ }^{25}$ Giddens A., Socjologia, PWN, Warszawa 2006, s.738.
} 
Trzecia grupa koncentruje się na zjawisku partycypacji. Wskazuje się tutaj na jednostki czy grupy, które należą do określonej wspólnoty w sensie geograficznym, ale nie partycypują w życiu obywatelskim. Maria Jarosz określając wykluczenie społeczne nawiązuje do „życia poza nawiasem praw i przywilejów społeczeństwa" ${ }^{26}$ Zdaniem Satya R. Chakravarty, Conchita D'Ambrosio i Akerlofowa George, wykluczenie społeczne wiąże się $\mathrm{z}$ ubóstwem i deprywacją potrzeb oraz brakiem uczestnictwa/partycypacji w życiu społecznym lub zbiorowym (utrata społecznych więzi - rodzinnych, przyjacielskich czy $\mathrm{z}$ instytucjami społecznymi), a także problemami związanymi $\mathrm{z}$ prawami społecznymi $\mathrm{i}$ socjalnymi (odmowa, niekorzystanie, problemy z realizacją) oraz z dostępem(ograniczony, utrudniony) do zasobów, dóbr publicznych, instytucji i systemów społecznych. ${ }^{27} \mathrm{Z}$ kolei Lucyna Frąckiewicz wykluczenie traktuje jako ,sytuację uniemożliwiająca lub też znacznie utrudniająca jednostce lub grupie pełnienie ról społecznych, korzystanie z dóbr publicznych i infrastruktury społecznej, gromadzenie zasobów i zdobywanie dochodów w godny sposób zgodnie z obowiązującym prawem". ${ }^{28}$ Podobny kontekst interpretacji wykluczenia społecznego prezentuje również Thomas Marshall, który definiuje je jako „niemożność stosowania praw obywatelskich, zarówno tych o charakterze ekonomicznym, politycznym, jak również uprawnień socjalnych". ${ }^{29}$ Według Narodowej Strategii Integracji Społecznej dla Polski wykluczenie społeczne to „brak lub ograniczenie możliwości uczestnictwa, wpływania i korzystania z podstawowych instytucji publicznych i rynków, które powinny być dostępne dla wszystkich, a w szczególności dla osób ubogich". 30

Przedstawione definicje wykluczenia akcentują przede wszystkim problem alienacji z życia społecznego i instytucjonalnego jednostek czy grup społecznych poprzez niemożności uczestniczenia $\mathrm{w}$ istotnych aspektach życia społeczno-gospodarczego i polityczno-kulturalnego danego społeczeństwa, które nie jest wynikiem indywidualnego wyboru jednostki lecz przeszkód jakie ona napotyka. ${ }^{31}$

Reasumując należy zaznaczyć, iż zjawisko ubóstwa, czy wykluczenia społecznego jest różnie interpretowane $w$ zależności od autora, miejsca występowania jak i czasu. ${ }^{32}$ Ubóstwo w zachodniej Europie ma inny wymiar, niż w biednych państwach afrykańskich. Ponadto gospodarstwo domowe o kondycji ekonomicznej dziś uznawanej

\footnotetext{
${ }^{26}$ Jarosz M., Wstęp [w:] M. Jarosz (red.), Naznaczeni i napiętnowani. O wykluczeniu politycznym, Oficyna Naukowa s.c., Warszawa 2008, s.8.

${ }^{27}$ Chakravarty S. R., Conchita D'A., The Measurement of Social Exclusion, Review of Income and Wealth 52 (3), 2006, s.377-398.

${ }^{28}$ Frąckiewicz L., Wykluczenie społeczne w skali makro i mikroregionalne [w:] L. Rąckiewicz (red.), Wykluczenie społeczne, Wydawnictwo Akademii Ekonomicznej im. K. Adamieckiego w Katowicach, Katowice 2005, s. 11.

${ }^{29}$ Golinowska S., Morecka Z., Stryc M., Cukrowska E., Cukrowski J., Od ubóstwa do wykluczenia społecznego. Badania. Koncepcja. Wyniki. Propozycje. Polska. Europa. Świat, IPiSS, Warszawa 2008, s.114.

${ }^{30}$ Narodowa Strategia Integracji Społecznej dla Polski, dokument Ministerstwa Gospodarki, Pracy i Polityki Społecznej, Warszawa 2004.

31 Sobczak, M., Wykluczenie społeczne i inkluzja społeczna z wykorzystaniem podmiotów ekonomii społecznej w Polsce na przykładzie województwa łódzkiego, Wydawnictwo Uniwersytetu Łódzkiego, Łódź 2016, s.13.

${ }^{32}$ Panek T., Ubóstwo, wykluczenie społeczne i nierówności. Teoria i praktyka pomiaru, Oficyna Wydawnicza SGH, Warszawa 2011, s.12
} 
za niewystarczająca jeszcze kilkadziesiąt lat temu nie byłoby klasyfikowane jako ubogie. $^{3.3}$

\section{Wyniki badań empirycznych}

W latach 2013-2016, pomimo ogólnej zamożności Unii Europejskiej, ubóstwo i wykluczenie społeczne na jej obszarze utrzymywało się na wysokim poziomie (tab. 1). W 2013 roku w UE-28 $122 \mathrm{mln}$ osób doświadczało różnych (z różnym natężeniem) deficytów - tzn. braku środków finansowych, braku dostępu do dóbr materialnych, czy też dostępu do pracy. W dużych miastach była to blisko jedna czwarta populacji (24,6\%), a na terenach wiejskich niecała jedna trzecia - ponad 27\% (tab. 1). W 2016 roku liczba osób zagrożonych omawianymi zjawiskami ogółem zmalała o ponad $4 \mathrm{mln}$ osób - w miastach o ponad 1,8 $\mathrm{mln}$ (4\%), a na wsi o ok. 2,2 $\mathrm{mln}$ (blisko 7\%).

Tabela 1. Wskaźnik zagrożenia ubóstwem lub wykluczeniem społecznym w Unii Europejskiej w relacji miasto-wieś w latach 2013-2016 [w\%]

\begin{tabular}{|c|c|c|c|c|c|c|c|c|}
\hline \multirow{2}{*}{ Kraje } & 2013 & 2014 & 2015 & 2016 & 2013 & 2014 & 2015 & 2016 \\
\hline & \multicolumn{4}{|c|}{ MIASTO } & \multicolumn{4}{|c|}{ WIEŚ } \\
\hline UE & 24,6 & 24,3 & 24 & 23,6 & 27,4 & 27,1 & 25,5 & 25,5 \\
\hline Austria & 26,8 & 28,3 & 24,9 & 24,7 & 14,4 & 14,1 & 13,9 & 14,8 \\
\hline Belgia & 30,2 & 28,6 & 29,7 & 29,3 & 19,5 & 21,1 & 19,1 & 19,7 \\
\hline Bułgaria & 38,4 & 30 & 31,7 & 31,1 & 59,8 & 51,4 & 54,8 & 53,8 \\
\hline Chorwacja & 22,2 & 22,8 & 20,3 & 20,9 & 36,3 & 34,9 & 34,9 & 33,5 \\
\hline Cypr & 25,1 & 25,1 & 24,9 & 23,7 & 30,4 & 31 & 33,1 & 32,2 \\
\hline Czechy & 13,7 & 13,9 & 13,8 & 14 & 15,2 & 15,2 & 12,8 & 11,4 \\
\hline Dania & 24,1 & 24,2 & 24,3 & 23,3 & 15,1 & 14,8 & 15,8 & 13,4 \\
\hline Estonia & 20,3 & 25 & 21,9 & 22,4 & 25,8 & 26,5 & 26,4 & 26,1 \\
\hline Finlandia & 14,9 & 16,6 & 16,8 & 17,2 & 17,1 & 17,8 & 17,2 & 17,1 \\
\hline Francja & 18,8 & 19,6 & 18,5 & 19,6 & 16,1 & 16,3 & 15,9 & 15,8 \\
\hline Grecja & 33,9 & 34,1 & 33,7 & 33,6 & 38,3 & 39,9 & 38,6 & 38,9 \\
\hline Hiszpania & 24 & 26,2 & 25,5 & 25,9 & 34,7 & 34,8 & 34 & 33,5 \\
\hline Holandia & 18,7 & 18,6 & 20,9 & 19,9 & 12,5 & 15,5 & 12,8 & 12,4 \\
\hline Irlandia & 26,4 & 26,3 & 25,2 & 23,9 & 31,6 & 27,9 & 25,3 & 22,4 \\
\hline Litwa & 23,6 & 21,8 & 22,3 & 20,8 & 37,8 & 32,4 & 34,7 & 37,6 \\
\hline Luksemburg & 17,6 & 16,1 & 16,8 & 20,1 & 16,2 & 16,6 & 15,7 & 15,7 \\
\hline Łotwa & 29,6 & 26,5 & 25,6 & 22,1 & 40,9 & 38,6 & 37 & 35 \\
\hline Malta & 24,1 & 23,7 & 22,8 & 20,4 & - & - & - & - \\
\hline Niemcy & 23,2 & 24,1 & 24,3 & 23,7 & 19,9 & 18,8 & 16,9 & 17,2 \\
\hline Polska & 19,8 & 17,8 & 16,7 & 16,2 & 32,5 & 31,2 & 30 & 27,9 \\
\hline Portugalia & 26,9 & 26,8 & 26,6 & 24,2 & 31,6 & 30,9 & 30 & 29 \\
\hline Rumunia & 33 & 27,2 & 24,1 & 24,3 & 52,7 & 51,9 & 50,8 & 51,7 \\
\hline Słowacja & 17,6 & 15 & 16,1 & 13 & 21,5 & 20,8 & 20,6 & 21,8 \\
\hline Słowenia & 20,4 & 20,2 & 19,5 & - & 21,7 & 21,6 & 19,4 & - \\
\hline Szwecja & 19,2 & 19,1 & 20,5 & 19,9 & 18,6 & 18,4 & 18,4 & 18 \\
\hline Wegry & 29,1 & 24 & 21,6 & 18,4 & 40,5 & 37,8 & 32,5 & 31,3 \\
\hline $\begin{array}{l}\text { Wielka } \\
\text { Brytania }\end{array}$ & 28,5 & 27 & 27,3 & 24,5 & 17,5 & 20,5 & 20 & 17,4 \\
\hline Włochy & 27,5 & 27,8 & 28,7 & 30,3 & 34,8 & 33,7 & 26,8 & 31 \\
\hline
\end{tabular}

- brak danych dla Malty

Źródło: opracowanie własne na podstawie danych Eurostat: http://ec.europa.eu/eurostat/statisticsexplained/index.php?title=Urban_Europe_\%E2\%80\%94_statistics_on_cities, towns_and_suburbs_\%E2\% $\% 0 \%$ 94_poverty_and_social_exclusion_in_cities\&oldid=345223 [odczyt: 12.05.2018].

${ }^{33}$ Sen A., Nierówności. Dalsze rozważania, Społeczny Instytut Wydawniczy Znak, Kraków 2000, s.98. 
W latach 2013-2016, w ujęciu względnym, wyższe ryzyko ubóstwa lub wykluczenia społecznego w UE-28 odnotowano wśród osób mieszkających na obszarach wiejskich niż w przypadku osób zamieszkających miasta. Należy jednak zaznaczyć, iż udział ludności zagrożonej powyższymi zjawiskami był szczególnie wysoki wśród mieszkańców dużych miast w znacznej części Europy Zachodniej , podczas gdy we wschodnich i południowych częściach UE częściej spotyka się najwyższe ryzyko ubóstwa wśród osób mieszkających na obszarach wiejskich.

W pięciu państwach Europy Zachodniej odsetek ludności zagrożonej ubóstwem lub wykluczeniem społecznym był najwyższy wśród mieszkańców miast: Belgii, Niemiec, Wielkiej Brytanii, Danii i Austrii - wartości wskaźnika powyżej 20\%. W 2016 roku udział ludności zamieszkującej austriackie, belgijskie oraz duńskie duże miasta, które były zagrożone ubóstwem, był blisko dwa razy większy niż udział takich osób zamieszkających na obszarach wiejskich.

W krajach Europy Południowej - Grecji, Hiszpanii, Portugalii, na Cyprze oraz we Włoszech odsetek osób zagrożonych ubóstwem i wykluczeniem społecznym był znacznie wyższy na terenach wiejskich - w badanych latach miernik przekraczał poziom 30\% (z wyjątkiem Portugalii w 2016 roku). Natomiast najwyższy poziom wskaźnika na terenach wiejskich odnotowano w dwóch państwach Europy Wschodniej - w Bułgarii i Rumunii, gdzie ponad 50\% mieszkańców tych obszarów zagrożonych było ubóstwem i wykluczeniem społecznym.

Polska znajduje się w czołówce państw Unii Europejskiej z najniższym poziomem zagrożenia ubóstwem lub wykluczeniem społecznym w dużych miastach - w 2016 roku wartość wskaźnika była niższa od średniego poziomu w UE o ponad 7 punktów procentowych. Natomiast na terenach wiejskich poziom wskaźnika był wyższy do przeciętnego w krajach Wspólnoty - w 2013 roku o 5 punktów procentowych a w 2016 o 2,4 punkty procentowe.

Rozpatrując osobno każdy z elementów przyczyniających się do zagrożenia ubóstwem bądź wykluczeniem społecznym widać zróżnicowane tendencje (tab. 2).

W większości krajów Wspólnoty obszary wiejskie charakteryzowały się wyższym stopniem zagrożenia ubóstwem relatywnym (tab.2). Różnice pomiędzy krajami były jednak bardzo wyraźne - na poziomie granicy ubóstwa nie osiągał dochodu co drugi mieszkaniec wsi w Rumunii, co trzeci w Bułgarii, co ósmy w Finlandii oraz co jedenasty w Danii i co dwunasty w Czechach. Ponadto 2016 roku w wskaźnik zagrożenia ubóstwem wśród osób zamieszkałych na obszarach wiejskich był w Rumunii blisko czterokrotnie wyższy niż w przypadku osób mieszkających w miastach, w Bułgarii i na Litwie trzykrotnie wyższy, podczas gdy w Szwecji i na Słowenii był tylko nieznacznie wyższy (o 0,6 i $2,8 \%$ ).

W ponad w połowie krajów UE-15 - w Luksemburgu, Austrii, Holandii, Wielkiej Brytanii, Belgii, Danii, Francji, Niemczech i Szwecji ubóstwem relatywnym zagrożeni byli w większym stopniu mieszkańcy miast. Przykładowo w 2014 roku udział ludności zamieszkującej austriackie miasta, które były zagrożone ubóstwem, był 2,0 razy większy niż udział osób mieszkających na obszarach wiejskich, podczas gdy ten sam wskaźnik w Belgii wynosił 1,6: 1 .

W Polsce wskaźnik zagrożenia ubóstwem relatywnym był ponad dwukrotnie wyższy na wsi niż w dużych aglomeracjach miejskich. Jednocześnie Polska zaliczała się do grona krajów charakteryzujących się najniższym poziomem granic ubóstwa. 
Ogólnie w latach 2013-2016 wskaźnik zagrożenia ubóstwem w dużych miastach unijnych zwiększył się, a na obszarach wiejskich utrzymywał się na relatywnie stabilnym poziomie. W 2016 roku wyraźny wzrost ubóstwa relatywnego w dużych miastach odnotowano w dwudziestu jeden krajach Wspólnoty, w tym największy w Estonii o blisko $35 \%$, na Łotwie o $32 \%$ i w Hiszpanii o $21 \%$, a w siedmiu spadek - największy w Grecji o $10 \%$. Na terenach wiejskich wyraźny wzrost ubóstwa relatywnego zaobserwowano w dwóch krajach: w Rumunii - o ponad 16\% oraz w Belgii - o 12\%.

Pomimo, że średni poziom deprywacji materialnej w krajach członkowskich UE był nieznacznie wyższy na obszarach wiejskich, to w 2016 roku w większości państw Wspólnoty (w piętnastu) to właśnie mieszkańcy dużych miast nie mogli zaspokoić swoich egzystencjonalnych potrzeb w większym stopniu niż mieszkańcy wsi (tab.2). Poziom deprywacji materialnej pomiędzy krajami Unii Europejskiej (EU-28), bez względu na obszar, był również bardzo zróżnicowany. W 2013 roku rozpiętość wskaźnika obliczonego dla dużych miast wynosiła 33,3 punkty procentowe. Najwyższy poziom deprywacji odnotowano w Bułgarii i Rumunii tj. odpowiednio 35,3\% i 26,1\%. Najniższą deprywację, poniżej 3\% odnotowano w 2013 r. tylko w Szwecji 1,9\%, w Luksemburgu - 2,1\% oraz w Finlandii 2,5\%. Na wsi wskaźnik pogłębionej deprywacji w 2013 roku wahał się od 0,9\% w Holandii do aż 52,1\% w Bułgarii. W 2016 roku w dużych miastach osiagał wartości od 1,2\% w Szwecji do 25\% w Bułgarii, a na terenach wiejskich od 0,5\% w Holandii i w Szwecji do 40,6\% w Bułgarii. Poziom wskaźnika w Bułgarii, która znacznie odstaje od pozostałych europejskich państw, jest bardzo niepokojący. Jak wynika z powyższych danych w kraju tym deprywacja materialna i społeczna dotyczy blisko połowy populacji wsi oraz jednej czwartej ludności dużych miast.

W Polsce w 2016 roku blisko 7\% osób zamieszkujących obszary wiejskie jak i duże miasta nie mogło zaspokoić przynajmniej $4 \mathrm{z} 9$ podstawowych potrzeb. W latach objętych badaniem widoczne było wyraźne zmniejszanie się deprywacji materialnej w Polsce - w miastach o niecałe, a na wsi o ponad $40 \%$.

Należy również odnotować, iż w badanym okresie przeciętne wartości wskaźnika pogłębionej deprywacji materialnej odnotowały spadek, co wskazuje na podniesienie poziomu życia w całej Unii Europejskiej (tab.2). W 2016 roku miernik ten w dużych miastach zmalał o 2,2 punkty procentowe do poziomu 7,7 \%, co oznacza 4,4 mln osób mniej niż w 2013 r., a na terenach wiejskich o 2,6 punkty procentowe - 3,5 mln osób.

W ciagu analizowanych lat blisko co ósmy mieszkaniec dużych aglomeracji oraz co dziesiąty obszarów wiejskich w wieku poniżej 59 lat mieszkał w rodzinie, w której dorośli pracowali mniej niż $20 \%$ ich potencjału pracy (tab. 2). Wskaźnik ten w dużych miastach i na wsi w Unii Europejskiej ogółem w 2016 roku tylko w nieznacznym stopniu zmniejszył się w stosunku do notowanego w 2013 roku.

W większości krajów Europy Zachodniej mieszkańcy miast w większym stopniu charakteryzowali się niską intensywnością pracy niż mieszkańcy obszarów wiejskich. W 2016 roku szczególnie wysoką różnicę pomiędzy analizowanymi obszarami zaobserwowano w trzech krajach: w Austrii - 60\%, w Niemczech - 53\% oraz w Belgii - 43\%. Natomiast w krajach dawnego bloku wschodniego to mieszkańcy obszarów wiejskich częściej niż w miastach żyli w gospodarstwach o niskiej intensywności pracy. W 2016 roku na Słowacji oraz w Bułgarii mieszkańcy wsi ponad trzykrotnie częściej charakteryzowali się niską intensywnością pracy niż mieszkańcy miast. W Polsce różnice pomiędzy obszarami były nieduże (średnio nie cały punkt procentowy) z niewielką przewagą na obszarach wiejskich. 
Tabela 2. Wskaźniki cząstkowe składające się na wskaźnik zagrożenia ubóstwem lub wykluczeniem społecznym w Unii Europejskiej w relacji miasto-wieś w latach 2013-2016 [w\%]

\begin{tabular}{|c|c|c|c|c|c|c|c|c|c|c|c|c|c|c|c|c|c|c|c|c|c|c|c|c|}
\hline \multirow{3}{*}{ Kraje } & \multicolumn{8}{|c|}{ Wskaźnik zagrożenia ubóstwem } & \multicolumn{8}{|c|}{ Wskaźnik poważnej deprywacji materialnej } & \multicolumn{8}{|c|}{ Wskaźnik niskiej intensywności pracy } \\
\hline & 2013 & 2014 & 2015 & 2016 & 2013 & 2014 & 2015 & 2016 & 2013 & 2014 & 2015 & 2016 & 2013 & 2014 & 2015 & 2016 & 2013 & 2014 & 2015 & 2016 & 2013 & 2014 & 2015 & 2016 \\
\hline & \multicolumn{4}{|c|}{ MIASTO } & \multicolumn{4}{|c|}{ WIEŚ } & \multicolumn{4}{|c|}{ MIASTO } & \multicolumn{4}{|c|}{ WIEŚ } & \multicolumn{4}{|c|}{ MIASTO } & \multicolumn{4}{|c|}{ WIEŚ } \\
\hline UE & 15,9 & 16,4 & 16,7 & 16,7 & 19,9 & 20,1 & 19,8 & 19,8 & 9,9 & 9,2 & 8,4 & 7,7 & 10,7 & 9,8 & 8,2 & 8,1 & 12,1 & 12,6 & 12,3 & 11,7 & 10,3 & 10,4 & 9,2 & 9,2 \\
\hline Austria & 20,9 & 20,9 & 19 & 19,2 & 11,4 & 10,5 & 10,3 & 11,6 & 9,2 & 7,9 & 6,2 & 6,2 & 1,4 & 1,2 & 1,6 & 1,6 & 12,9 & 15,5 & 13,1 & 13,5 & 4,5 & 5,3 & 5,3 & 5,3 \\
\hline Belgia & 24,1 & 22,1 & 22 & 23,5 & 12,8 & 14,2 & 12,8 & 14,4 & $\begin{array}{l}9,8 \\
\end{array}$ & 10,2 & 10,1 & 8,4 & 3,2 & 6,2 & 4,1 & 4,7 & 21,4 & 20,9 & \begin{tabular}{|l|}
21,7 \\
\end{tabular} & 21,7 & 14,2 & 14,7 & 13,1 & 12,3 \\
\hline Bułgaria & 10,7 & 12,3 & 12,4 & 14 & 33,9 & 33,7 & 35,8 & 36,6 & 35,3 & 25,9 & 27,7 & 25 & 52,1 & 40,6 & 42,6 & 40,6 & 6,5 & 7,7 & 6,1 & 7 & 23,1 & 20 & 23 & 21,9 \\
\hline Chorwacja & 11,7 & 12,7 & 11,1 & 11,9 & 25,6 & 24,4 & 26,5 & 26,6 & 11,5 & 12,1 & 11,7 & 9,6 & 17,9 & 16,9 & 15,4 & 13,5 & 11,2 & 13,1 & 10,4 & 11,6 & 17,1 & 15,8 & 16,9 & 15,4 \\
\hline Cypr & 12,5 & 12,6 & 13,6 & 13,2 & 18 & 16,1 & 18,1 & 18,3 & 15,4 & 14 & 12,7 & 11,5 & 17,5 & 17,7 & 18,8 & 16,2 & 7,7 & 8,9 & 10 & 10,3 & 7,4 & 10,6 & 11,2 & 10,7 \\
\hline Czechy & 7,6 & 8,4 & 9,1 & 10,1 & 9,5 & 10,7 & 9,1 & 8,5 & 7 & 7,7 & 6 & 5,4 & 6,1 & 5,4 & 4 & 3,7 & 6,8 & 8 & 7,4 & 6,8 & 6,9 & 6 & 4,8 & 5,6 \\
\hline Dania & 16,2 & 17 & 17,5 & 17,5 & 9,7 & 9,5 & 10,5 & 9,1 & 4,6 & 4,9 & 3,6 & 3,5 & 2,6 & 2,6 & 4,1 & 2,3 & 16,7 & 17,6 & 16,5 & 13,2 & 9,2 & 9,1 & 9,7 & 9,1 \\
\hline Estonia & 14,4 & 20,2 & 19 & 19,4 & 21,8 & 23,3 & 24,1 & 23,6 & 8,1 & 6,7 & 4,5 & 4,6 & 6,4 & 4,9 & 4,3 & 5 & 6,1 & 6,1 & 5 & 4,1 & 10,4 & 9 & 8,4 & 7,7 \\
\hline Finlandia & 10,4 & 12,1 & 11,5 & 11 & 13,1 & 13,4 & 13,8 & 12,8 & 2,5 & 3,1 & 2,3 & 2,2 & 2,5 & 2,3 & 1,8 & 2,3 & 8,8 & 10,3 & \begin{tabular}{|l|}
12,4 \\
\end{tabular} & 13,9 & 8,9 & 8,7 & 8,4 & 9,1 \\
\hline Francja & 14,1 & 14,2 & 13,9 & 14,2 & $\begin{array}{ll}11,9 \\
\end{array}$ & 11,6 & 12,6 & 12,1 & 5,8 & 6 & 5,7 & 5,6 & 4,1 & 3,2 & 2,5 & 2,7 & 8,8 & 10,7 & \begin{tabular}{|l|}
10,2 \\
\end{tabular} & 9,2 & 5,5 & 7,4 & 5,7 & 6 \\
\hline Grecja & 20,4 & 19,1 & 17,6 & 18,3 & 26,7 & 27 & 26,5 & 26,1 & 20,1 & 21,2 & 22,1 & 21,6 & 20,7 & 23,7 & 22,1 & 23,9 & 19,3 & 19,4 & \begin{tabular}{|c|}
18,1 \\
\end{tabular} & 17,8 & 17,2 & 15,9 & 14,7 & 15,8 \\
\hline Hiszpania & 16,6 & 19 & 19 & 20,1 & 27,6 & 27,9 & 27,6 & 28 & 6,7 & 7,3 & 6,5 & 6,2 & 5,8 & 6,4 & 5,3 & 5,2 & 14,7 & 16,2 & \begin{tabular}{|l|}
14,4 \\
\end{tabular} & 14 & 18,9 & 18,8 & 16,3 & 17,2 \\
\hline Holandia & 12,2 & 12,3 & 14,4 & 14,9 & 8,7 & 11,5 & 10,2 & 10,1 & 3,3 & 4,1 & 3,8 & 3,8 & 0,9 & 0,9 & 0,6 & 0,5 & 11,3 & 13,1 & \begin{tabular}{|l|}
13,9 \\
\end{tabular} & 12,4 & 6,6 & 8,7 & 7,3 & 6,3 \\
\hline Irlandia & 11,8 & 13,1 & 14,1 & 15,1 & 19,5 & 19,7 & 18,3 & 17,1 & 10,8 & 9,8 & 9,4 & 8,6 & 7,6 & 5,5 & 4,7 & 2,9 & 21,9 & 20,5 & 20 & 17,6 & 24,9 & 21,2 & 17,2 & 15,9 \\
\hline Litwa & 11,8 & 11,9 & 13,7 & 11,5 & 29,4 & 25,2 & 28,7 & 30,1 & 15,6 & 13,8 & 12,5 & 12,5 & 16,4 & 14,4 & 15 & 14,4 & 7,1 & 6,6 & 6,2 & 5,4 & 15,2 & 11,8 & 11,4 & 14,1 \\
\hline Luksemburg & 15,9 & 13,9 & 14,1 & 17,5 & 12,7 & 14 & 12,1 & 11,7 & 2,1 & 1,4 & 2,6 & 1,7 & 1,3 & 1,1 & 1,5 & 0,9 & 4,7 & 4,8 & 6,8 & 5,2 & 6,7 & 5,1 & 5,5 & 6,4 \\
\hline Lotwa & 12,7 & 14,9 & 16,8 & 16,3 & 26 & 27 & 29,2 & 27,7 & 21,5 & 16,2 & 13,1 & 9,3 & 26,4 & 21,8 & 19,4 & 15,8 & 8,9 & 6,3 & 6,7 & 6 & 11,1 & 12,3 & 9,3 & 9 \\
\hline Malta & 15,6 & 15,5 & 16,4 & 16,8 & - & - & - & - & 9,7 & 10,4 & 8,7 & 4,7 & - & - & - & - & 9,4 & 10,4 & 9,7 & 7,7 & - & - & - & - \\
\hline Niemcy & 18,3 & 19,3 & 19,9 & 19,4 & 16,4 & 15,3 & 14,5 & 15 & 6,3 & 6,3 & 6,2 & 4,8 & 5,3 & 4,2 & 2,9 & 2,7 & 14,2 & 14,4 & 14,4 & 13,4 & 6,9 & 6,8 & 6,4 & 6,3 \\
\hline Polska & 10,6 & 9,6 & 9,6 & 10,9 & 25 & 24,1 & 24,8 & 23,9 & 11,1 & 9,4 & 8,1 & 6,8 & 12,6 & 11,2 & 8,8 & 7 & 6,8 & 6,3 & 6,8 & 6 & 7 & 7,9 & 7,1 & 6,8 \\
\hline Portugalia & 17,1 & 18,1 & 18,2 & 17,3 & 23,8 & 23,8 & 24,2 & 24 & 13,3 & 12,8 & 11,8 & 9,4 & 8,5 & 8,4 & 7,9 & 7,4 & 12,6 & 12,7 & 11,4 & 9,4 & 13,7 & 13,7 & 12,3 & 10,4 \\
\hline Rumunia & 10,2 & 9,2 & 11,1 & 10,3 & 34,5 & 38,4 & 40,4 & 40,1 & 26,1 & 20,4 & 16,8 & 17,2 & 35,6 & 30,8 & 29 & 29,6 & 6,8 & 5,4 & 6,1 & 5,9 & 7,8 & 7,8 & 9,3 & 8,5 \\
\hline Słowacja & 8 & 8,2 & 9,2 & 7 & 15,4 & 16,2 & 15 & 17,3 & 10,4 & 7,9 & 7 & 6,2 & 10,3 & 10,9 & 9,4 & 8,7 & 3,3 & 2,6 & 3 & 2,2 & 10 & 9,9 & 9,5 & 8,3 \\
\hline Słowenia & 13,9 & 14,2 & 14,8 & 14,6 & 16 & 16 & 14,8 & 14,7 & 7,5 & 6,3 & 5,2 & 5,5 & 6,6 & 6,8 & 5,9 & 4,8 & 9 & 9,5 & 7,9 & 7,3 & 8,3 & 8,9 & 6,8 & 7 \\
\hline Szwecja & 16,7 & 15,9 & 17,8 & 17,3 & 16,9 & 16,1 & 16 & 16,5 & 1,9 & 1,7 & 1 & 1,2 & 0,9 & 0,3 & 1,5 & 0,5 & 9 & 9,9 & 9,8 & 9,7 & 9,4 & 8 & 7,7 & 7,2 \\
\hline Wegry & 7,9 & 6,6 & 9,3 & 7,4 & 21,9 & 21 & 18,7 & 18,9 & 23,4 & 18,8 & 14,4 & 11,2 & 31,5 & 27,6 & 22,3 & 19,3 & 9,7 & 8,8 & 8,2 & 6,2 & 18,6 & 14,4 & 10 & 8,3 \\
\hline Wielka Brytania & 17,9 & 18,6 & 18,8 & 17,2 & 12,6 & 14,7 & 15,5 & 12,6 & 10,3 & 9,5 & 7,9 & 6,4 & 2,7 & 3,7 & 3,4 & 2,4 & 15,4 & 13,9 & 13,6 & 12,4 & 9,2 & 10,1 & 8 & 8,2 \\
\hline Włochy & 18,3 & 18,5 & 19,3 & 20,6 & 25,4 & 24,8 & 20,2 & 22 & 12,2 & 11,5 & 12 & 14,2 & 13,7 & 11,4 & 7,7 & 10,5 & 10,8 & 12 & 12 & 14,4 & 15,7 & 15,5 & 11,2 & 12,2 \\
\hline
\end{tabular}


Zbadano za pomocą współczynnika korelacji Pearsona zależności występujące pomiędzy wartościami wskaźnika zagrożenia ubóstwem i wykluczeniem społecznym a trzema jego podwskaźnikami (tab.3).

Tabela 3. Współzależność wskaźników ubóstwa i wykluczenia społecznego w krajach Unii Europejskiej*

\begin{tabular}{|l|c|c|}
\hline \multirow{2}{*}{ Zmienne X/Y } & \multicolumn{2}{|c|}{ Wskaźnik zagrożenia ubóstwem lub wykluczeniem społecznym } \\
\cline { 2 - 3 } & MIASTO & WIES \\
\cline { 2 - 3 } & $\mathrm{r}(\mathrm{X}, \mathrm{Y})$ & $\mathrm{r}(\mathrm{X}, \mathrm{Y})$ \\
\hline Wskaźnik zagrożenia ubóstwem & 0,66 & 0,96 \\
\hline Wskaźnik poważnej deprywacji materialnej & 0,63 & 0,99 \\
\hline Wskaźnik niskiej intensywności pracy & 0,58 & 0,66 \\
\hline
\end{tabular}

*Wartość badanych współczynników została wyliczona na podstawie średniej z lat 2013-2016

Źródło: opracowanie własne na podstawie tabeli 1,2.

Spośród zbadanych miar w krajach Unii Europejskiej najwyżej skorelowany ze wskaźnikiem zagrożenia ubóstwem i wykluczeniem społecznym był wskaźnik poważnej deprywacji materialnej oraz wskaźnik zagrożenia ubóstwem. Współczynnik korelacji Pearsona obliczony dla terenów wiejskich osiagną̧ wartość odpowiednio $r=0,99$ i $\mathrm{r}=0,96$. Można zatem stwierdzić, że wzrost powyżej deprywacji materialnej oraz ubóstwa relatywnego przyczynia się do wzrostu liczby osób zagrożonych ubóstwem i wykluczeniem społecznym na obszarach wiejskich w krajach Unii Europejskiej. Zależności obliczone dla dużych miast pokazują istnienie silnej zależności pomiędzy zmiennymi.

Wyniki oszacowania pomiędzy wskaźnikiem zagrożenia ubóstwem i wykluczeniem społecznym a wskaźnikiem niskiej intensywności pracy obliczonych dla dużych aglomeracji miejskich wykazują zależność umiarkowaną - jedna zmienna wyjaśnia drugą w $35 \%$.

\section{Wnioski}

$\mathrm{Na}$ podstawie badań opisanych w niniejszym artykule można sformułować następujące wnioski:

1. W dyskursie naukowym można odnaleźć różnorodne definicje ubóstwa i wykluczenia społecznego, co stanowi poważny problem. Powszechność różnych kontekstów definicyjnych zwiększa bowiem ich nieostrość i przypadkowość. Przyjęte definicje stają się często punktem odniesienia do lepszego poznania i zrozumienia zjawiska, a także są pochodną celów i priorytetów działań instytucjonalnych.

2. W 2016 roku 23,4\% populacji Unii Europejskiej było zagrożonych ubóstwem lub wykluczeniem społecznym. Oznacza to, że osoby te znajdowały się w jednym z trzech stanów: zagrożenia ubóstwem z powodów dochodowych, poważnego zagrożenia niedostatkiem materialnym lub zamieszkiwały $\mathrm{w}$ gospodarstwie domowym o bardzo niskiej intensywności pracy.

3. Oceniając w Unii Europejskiej ryzyko ubóstwa i wykluczenia społecznego w ujęciu terytorialnym można zauważyć wyższy ich poziom pośród mieszkańców wsi. Jednakże w latach objętych badaniem różnice pomiędzy analizowanymi 
obszarami zmniejszały się. W 2013 roku przeciętnie w UE zagrożenie ubóstwem i wykluczeniem społecznym było wyższe o ponad $11 \%$ na wsi niż w dużych miastach, a w 2016 roku wyższe o $8 \%$.

4. Ubóstwo relatywne w większym stopniu dotykało mieszkańców wsi niż mieszkańców dużych miast unijnych. Średnio we Wspólnocie na terenach wiejskich co piąta osoba nie osiagnęła dochodu na poziomie granicy ubóstwa, a w miastach - blisko co szósta.

5. Wskaźnik poważnej deprywacji materialnej w dużych miastach i na terenach wiejskich kształtował się na zbliżonym poziomie i bez względu na obszar ulegał systematycznemu zmniejszeniu. W większości krajów Europy Zachodniej to mieszkańcy dużych aglomeracji miejskich częściej nie mogli zaspokoić wszystkich potrzeb egzystencjonalnych. Odwrotna sytuacja występowała w nowych krajach członkowskich.

6. Od 2014 roku w większości krajów Unii gospodarstwa domowe mieszkańców miast w nieco większym stopniu charakteryzowały się niską intensywnością pracy niż mieszkańców obszarów wiejskich. Średnio 12\% ludności dużych miast oraz $10 \%$ obszarów wiejskich na obszarze Wspólnoty w wieku poniżej 59 lat mieszkało w rodzinie o niskiej intensywności pracy.

\section{Bibliografia}

Becker-Pestka D., Kubiński G., Łojko M., Różne obszary wykluczenia społecznego w Polscewybrane zagadnienia, Exante, Wrocław 2017.

Błaszczak-Przybycińska I., 1990, Metody pomiaru granic ubóstwa, Wiadomości Statystyczne nr 11, GUS, Warszawa 1990, s.49-61.

Boczoń J., Toczyski W., Zielińska A., Natura i kwestia ubóstwa, Ośrodek Badaně Społecznych, Gdańsk - Warszawa 1991.

Chakravarty S. R., Conchita D'A., The Measurement of Social Exclusion, Review of Income and Wealth 52 (3):, 2006, s. 377-398.

Combating poverty and social exclusion: A statistical portrait of the European Union 2010, Eurostat,

http://2010againstpoverty.europa.euhttp://2010againstpoverty.europa.eu

Chmielewski P., Znaczenie definicji biedy w wyznaczaniu granicy ubóstwa, Finanse i Prawo Finansowe, Journal of Finance and Financial Law, Łódź 2016, s.37-50.

Dyczewski L., Kościół katolicki wobec ubóstwa i ludzi ubogich, [w:] Polska bieda II, red. S. Golinowska, IPiSS, Warszawa 1997.

Estivill J., Concepts and Strategies for Combating Social Exclusion. An overview, International Labour Office, Genewa 2003.

Frąckiewicz L., Wykluczenie społeczne w skali makro i mikroregionalne [w:] Wykluczenie społeczne, Wydawnictwo Akademii Ekonomicznej im. K. Adamieckiego w Katowicach, Katowice 2005.

Frieske K., 1997, Bieda - miary i interpretacje [w:] S. Golinowska (red.), Polska bieda. Kryteria. Ocena. Przeciwdziałanie, IPiSS, Warszawa 1997.

Giddens A., Socjologia, Wyd. PWN, Warszawa 2006.

Golinowska S., Morecka Z., Stryc M., Cukrowska E., Cukrowski J., Od ubóstwa do wykluczenia społecznego. Badania. Koncepcja. Wyniki. Propozycje. Polska. Europa. Świat, IPiSS, Warszawa 2008. 
Golinowska S., Wykluczenie społeczne, [w:] S. Golinowska, Z. Morecka, M. Styrc, E. Cukrowska, J. Cukrowski (red.), Od ubóstwa do wykluczenia społecznego, IPiSS, Warszawa 2008.

Gore C., Figueiredo J.B., Wykluczenie społeczne i polityka przeciwdziałania ubóstwu, Problemy Polityki Społecznej, nr. 5, IPISS, Warszawa 2003.

Grewiński M., Polityka przeciwdziałania wykluczeniu społecznemu w Polsce i UE [w:] M. Sabal (red.), Potencjał tkwi w relacjach. Działania Regionalnego Ośrodka Polityki Społecznej w Krakowie na rzecz poprawy relacji międzyludzkich, Regionalny Ośrodek Polityki Społecznej, Kraków 2014.

http://ec.europa.eu/eurostat/statistics-

explained/index.php?title=Urban_Europe_\%E2\%80\%94_statistics_on_cities,_towns_and_suburbs $\% \mathrm{E} 2 \% 80 \% 94$ poverty_and_social_exclusion_in_cities\&oldid $=345223$

Jarosz M., Wstęp [w:] M. Jarosz (red.), Naznaczeni i napiętnowani. O wykluczeniu politycznym, Oficyna Naukowa s.c., Warszawa 2008.

Kumor I., Ubóstwo ujęcie teoretyczne, Edukacja Humanistyczna nr 1 (24), Towarzystwo Wiedzy Powszechnej, Szczecin 2011.

Moisio P., The Nature of Social Exclusion - Spiral of Precariousness or Statistical Category?, [w:] Social Exclusion in European Welfare States, ed. by R.J.A. Muffels, P. Tsakloglou, D.G. Mayes, Edward Elgar Publishing, Cheltenham UK/Northampton USA 2002.

Narodowa Strategia Integracji Społecznej dla Polski, dokument Ministerstwa Gospodarki, Pracy i Polityki Społecznej, Warszawa 2004.

Nowak A. Pojecie, istota, przyczyny, mechanizmy marginalizacji i wykluczenia społecznego http://bazhum.muzhp.pl/media//files/Chowanna/Chowanna-r2012-t1/Chowanna-r2012-t1-s1732/Chowanna-r2012-t1-s17-32.pdf

Panek T., Ubóstwo, wykluczenie i społeczne nierówności, Oficyna Wydawnicza Szkoła Główna Handlowa w Warszawie, Warszawa 2011.

Polska w Unii Europejskiej w 2004-2014, GUS, Warszawa 2014.

Rusnak Z., Pomiar ubóstwa i wykluczenia społecznego - problemy metodologiczne, Zeszyty Naukowe Wyższej Szkoły Bankowej we Wrocławiu Nr 20/2011, Wrocław 2011, s.387-408.

Samuelson P., Nordhaus W., Ekonomia, Rebis, Poznań 2014.

Sen A., Nierówności. Dalsze rozważania, Społeczny Instytut Wydawniczy Znak, Kraków 2000.

Sobczak, M., Wykluczenie społeczne i inkluzja społeczna z wykorzystaniem podmiotów ekonomii społecznej w Polsce na przykładzie województwa łódzkiego, Wydawnictwo Uniwersytetu Łódzkiego, Łódź 2016.

Szopa B., Wokół zagadnień ubóstwa i bogactwa, Uniwersytet Ekonomiczny w Krakowie, Kraków 2012.

\section{Summary}

The article addresses issues related to measuring poverty and social exclusion in large cities and rural areas of the European Union and examines the essence of these phenomena. It was written on the basis of source literature and statistical data from Eurostat. In the theoretical part, definitions and standards used to assess the analysed social phenomena were presented. The results confirmed that the risk of poverty and social exclusion is higher in rural areas of the European Community. Furthermore, it was noted that in most EU countries relative poverty is higher in rural areas, whereas severe material deprivation and low labour intensity are characteristic of large urban areas.

Key words: poverty, poverty lines, social exclusion, income, material deprivation, low work intensity 
Informacja o autorach:

Dr Malgorzata Raczkowska

Katedra Ekonomii i Polityki Gospodarczej

Wydział Nauk Ekonomicznych

Szkoła Główna Gospodarstwa Wiejskiego e-mail: malgorzata_raczkowska@sggw.pl ORCID: 0000-0002-8540-8958

Dr Kinga Gruziel

Katedra Ekonomii i Polityki Gospodarczej Wydział Nauk Ekonomicznych

Szkoła Główna Gospodarstwa Wiejskiego e-mail: kinga_gruziel@sggw.pl

ORCID: 0000-0003-2429-3795 